Walisongo: Jurnal Penelitian Sosial Keagamaan

Vol. 28 No. 2 (2020) pp. $145-170$

DOI: $10.21580 /$ ws.28.2.6985

\title{
Political Promises in the Lens of Islamic Theology and Jurisprudence: A Case Study of Surabaya Mayor Election 2020
}

\author{
M. Asrorun Niam Sholeh ${ }^{1 *}$ \\ ${ }^{1}$ Universitas Islam Negeri Syarif Hidayatullah Jakarta, Indonesia
}

\begin{abstract}
This research studied the status of political promises declared by Mayor candidates of Surabaya election 2020 during their campaigns started from September 26, 2020. It was field-library research with qualitative analysis. Data were collected by observing online media that particularly reports the election's campaign activities. They were then analyzed by using Islamic theology and jurisprudence approaches combined with structural-functionalism, symbolic interactionism, and social contract theories. It found four main remarks: first, Quranic verses and Prophetic traditions as theological underpinnings have definitely guided moral standards of Islamic politics, especially how to make such political promises. Secondly, the political realism of promises is a language of transactional politics and communication practice. Thirdly, political promises could only be legitimated by fulfilling strike pre-requirements and within very urgent conditions. Finally, the legal status of political promises must be contextual and conditional.
\end{abstract}

Penelitian ini mengkaji status bukum janji politik yang dinyatakan oleh kandidat Walikota (dan wakilnya) selama masa kampanye Pilkada Surabaya tahun 2020. Penelitian ini adalab penelitian lapangan-kepustakaan dengan jenis penelitian kualitatif. Data dikumpulkan melalui observasi media online yang khusus melaporkan aktivitas-aktivitas kampanye Pilkada tersebut. Data tersebut kemudian dianalisis dengan pendekatan teologi dan jurisprudensi

*Corresponding Author: M. Asrorun Niam Sholeh (asrorun.niam@uinjkt.ac.id), Jl. Ir H. Juanda No. 95, Ciputat., Tangerang Selatan, Indonesia 15412.

ISSN 0852-7172 (p) 2461-064X (e)

(C) 2020 by Author, published by Walisongo: Jurnal Penelitian Sosial Keagamaan

https://journal.walisongo.ac.id/index.php/walisongo 


\section{ASRORUN NIAM SHOLEH}

Islam serta paduan dari teori fungsionalisme struktural, interaksionisme simbolik, dan kontrak sosial. Penelitian ini menemukan empat poin utama; pertama, al-Quran dan Hadits menyugubkan standar moral dan batas-batas bagi praktik politik Islami. Kedua, realitas janji politik sebagai bahasa komunikasi dan politik transaksional. Ketiga, janji politik baru dapat dilegitimasi apabila memenubi persyaratan ketat dan dalam kondisi keterdesakan. Dan keempat, hukum Figh bagi janji politik beserta konsekuensi logis turunannya harus ditafsil/diperinci, sesuai karakteristik dan konteksnya.

Keywords: political promises; Surabaya Mayor Election 2020; Islamic theology and jurisprudence

\section{Introduction}

Political promises during the campaign period are a social phenomenon that always occurs. Political promises are part of political language and its communication. As a language of communication, political promises are aimed as popular as possible so that they can be digested and accepted by the audiences to attract sympathizers (Octania, 2019). In conveying this political communication, the campaign is the most important event in introducing candidates to the public. Their respective success teams assist the candidateto formulate various strategies and plans during this political campaign (Fatimah, 2018).

In campaigning and delivering political promises, candidates often cited the Quranic verses and Prophetic traditions. It is not uncommon for campaigns to be accompanied by the practice of money politics, which leads to practices of corruption, collusion, and nepotism (Puyu, 2016). On the other hand, by realizing the political realism that tend to be pragmatic, the public perceives candidates' political promises in various ways. The variety of perceptions depends on the public's psychological situation andultural and social backgrounds (Suseno \& Putra, 2014).

When communicating with constituents, candidates ensure a wide variety of transactions. At the very least, there are complementary transactions, cross transactions, and hidden transactions. These various transactions are candidate strategies to attract sympathy. In the future, 
when they are elected, the various aspirations accommodated from the community are distributed in such an arrangement to maintain the level of trust of their constituents (Safrun et al., 2020).

After the inauguration, the elected and officiated candidates are responsible for fulfilling their political promises. One of the people's efforts to fulfill political promises is the formation of regional regulations, according to previous political promises during the campaign period. The commitment of the elected leaders to their political promises is reflected in the extent to which regional regulations are created (Magdalena, 2018).

The electors have the right to collect promises from the elected people's representatives through the court as regulated in Article 1313 of the Civil Code (Awalin et al., 2018). In 2009, the Lembaga Pemilih Indonesia (LPI) filed a lawsuit against the elected President and Vice President, Susilo Bambang Yudhoyono and M. Jusuf Kalla, for failing to fulfill on political promises in the 2004 elections. However, the Jakarta court decision with the number 17 /PDT.G/2009/PN.JKT.PST states that political promises are insufficient for legal regulations regarding agreements in accordance with Article 130 of the Civil Law (Susmayanti, 2019).

Promises in certain corridors and contexts lead to a siyasab (political) contract. In Islam, a leader, who has not succeeded in fulfilling his promises in the world, will be insisted in the afterlife (Suwandi, 2019, p. 132). In the context of state life, the frequent failure of the government to realize political promises has prompted some people to miss the New Order totalitarianism style (Monib \& Bahrawi, 2011, p. 287).

This siyasah contract has the potential to metamorphose into transactional politics, which is characterized by food politics, money politics, and high-cost politics. Meanwhile, transactional politics undermines the realization of democratic elections, and the implementation of the election process becomes less democratic; triggering public distrust of political parties, giving birth to corrupt government officials. Moreover, regional autonomy is no longer relevant to improving the welfare and quality of the society life (Solihah, 2017). 


\section{ASRORUN NIAM SHOLEH}

Transactional politics in political science study include the category of political practice that brings the nation's mentality to the mafsadat or failure. Because, psychologically, day by day the people raise the politics of giving is considered as the normal case, it is considered as a pro-people act, not against an individual or collective values, so that each individual has the capital and the opportunity to carry out the transactional politics (Rizkika et al., 2019).

On the other hand, Islam also has moral rules that govern political promises and agreement. Islamic Sharia jurisprudence has contractual principles, such as the principle of taubid, the principle of permissibility, freedom of contract, justice, equality, honesty, trust, expediency and benefit, consensual, binding promises, the balance of achievement, legal certainty, and personality (Muayyad, 2015). The Islamic Jurisprudence (fiqh) scholars agreed that fulfilling promises that brought benefit were an obligation. On the other hand, keeping promises that are contrary to religion is prohibited (haram) (Tim Dakwah Pesantren, 2015).

This study specifically discusses political promises during the mayor election campaign in Surabaya 2020. The campaign is started from September 26 and the voting process will be in December 9, 2020. For the researcher, this election becomes important since it marks the change of the female mayor Tri Rismaharini who many Surabayan people witnessed as a brilliant and successful mayor in advancing Surabaya in terms of the city good governance. Her political campaign-successor would also be regarded as a remarkable point in winning the majority votes. The researcher sees that political promises are not enough to be seen from just the promise itself's legal status. Still, Islamic theology and jurisprudence must also look at the legal status of its derived social systems, the agents involved and interacting among them, fellow political agents, the roles and functions they play, and how Islamic Law responds to the pragmatic political in reality.

The study is field-library research with a qualitative analysis. It means that it combines a field and literary sources (Zed, 2004, p. 1). As literature research, various literature relating to the theme of political promise, 
Islamic theology, and Jurisprudence regarding Muslims' behavior during the campaign period is the primary data.

According to Koentjaraningrat, qualitative research aims to collect, classify, analyze, and interpret facts and relationships between natural facts, society, human behavior, and spirituality to discover new knowledge principles and methods to present things (Suwendra, 2018, p. 4). Qualitative analysis is used here to look at socio-political issues and Islamic jurisprudence more in-depth and more critical, especially concerning political realities since the campaign period, the socialization of political promises, political transactions between candidates and constituents, to the implementation of policies that tend to be collusive.

The approach used in this research is Islamic theology and jurisprudence combined with a sociological perspective. According to Atho Mudzhar, applying a sociological approach in the study of Islamic jurisprudence is useful in understanding deeper the social phenomena surrounding Islamic jurisprudence (Ahmad, 2001, p. xx). This approach is important because it can be used to see the sociological aspects and the reasoning of Islamic jurisprudence to answer the status of political appointments that often occur during campaign periods.

One of the sociological paradigms is related to social functions and structures, which see each element in society playing its respective roles and functions. Structural functionalism is a paradigm that emphasizes order and ignores social conflicts and changes in society. The main concern is about function, dysfunction, latent function, manifest function, and balance (Anwar \& Adang, 2008, p. 69). The campaign stage provided by laws and regulations has the function of creating other social categories, such as candidates who will advance to seize power, constituents who are ready to support each candidate's vision and mission, and groups of political brokers who often damage the positive image of democracy.

These social elements play their functions and roles to form a social system and involve a process of interaction between agents. This interaction is a way of communicating and the act of making political contracts. The 


\section{ASRORUN NIAM SHOLEH}

structural-functionalism used in this study is complemented by a symbolic interactionism paradigm, namely an analysis of how social actors interpret symbols, language, including political language in the form of promises from candidates. The meaning obtained from the interpretation process is used as the basis for social action (Susan, 2009, p. 50).

In the context of this symbolic interaction, candidates or politicians interact with each of their constituents to talk about a vision and mission that can be fought for together. In this interaction, mutual agreements are also built. Therefore, the theory of symbolic interactionism and social contract as part of the sociological paradigm is also used in this research. This social contract views that the morality and/or political obligations of an individual are very much determined by the contract or agreement between them in building the society of which the individual is a part (Karim, 2020, p. 50).

Finally, the complexity of the socio-political reality which is the background for the occurrence of political promise, will also be seen from Islamic jurisprudence itself. Basically, Islamic jurisprudence is extracted from the Koran and Tradition with a full social values methodology. The methodology or manhaj of extracting Islamic law is known as Islamic Law's discipline (Ușūl al-Fiqh). The science of Ushul Fiqih is a set of logical-philosophical principles in Islam for producing Islamic jurisprudence (Yasid, 2019, p. 77). Meanwhile, the legal product produced by Ușūl al-Fiqh is called Fiqh or Islamic jurisprudence.

With this Islamic Law (Usul Fiqh and Islamic fiqih), the status of political promises can be studied in a more philosophical as well as practical way. Therefore, the Islamic law (Ușūl al-Fiqh) is used as an approach in this study to determine Islamic jurisprudence's methodological reasoning in responding to the complexity of political promises during the campaign period. Meanwhile, the science of islamic jurisprudence is used as an approach to provide practical answers to the problem of political promise status and its various derivations in the form of socio-political behavior. 
The concept chart for analyzing the object of this research material can be described in Figure 1.

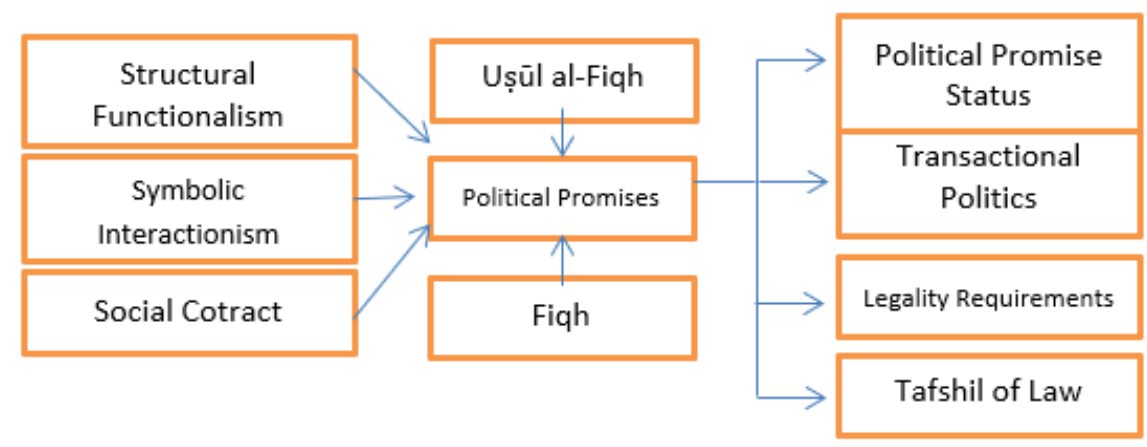

Figure 1. The concept chart for analyzing the object of this research

From the above chart, political promises seen from the approach of Islamic jurisprudence and theology, ontologically, can be found in the main sources of Quran and Prophetic Tradition (hadith). Epistemologically, with Ușūl al-Fiqh and Fiqh's approach, Political Promises are understood as legal objects with a status that can be interpreted (in detail) and as legal objects as long as they meet certain requirements. Meanwhile, from a study with a sociological approach, Political Promises are more likely to manifest transactional political practices.

\section{The Stages of Surabaya Mayor Election 2020}

As informed online from the East Java Kominfo, the stage of the Mayoral election 2020 in accordance with the draft of KPU (General Election Commission) Regulation Planning consists of two stages, namely the preparation and maintenance stage. For the preparation part, there are: (1) Program and budget planning are scheduled for September 30, 2019, (2) Compilation and Signing of the District Grant Agreement Manuscript (NPHD) on October 1, 2019, (3) Program and budget management, (4) Preparation of Rules and Decisions for the Conduct of the election August 31, 2019, (5) Socialization to the community and technical guidance of the Provincial KPU. KPU Kabupaten/kota, PPK, PPS 


\section{ASRORUN NIAM SHOLEH}

and KPPS on November 1, 2019, (6) Formation of PPK, PPS and KPPS working hours fund as at 31 January 2020, (7) Notification and registration of election monitoring January 31, 2020, (8) Management of the population list of potential voter turnout (DP4) on February 20, 2020 and (9) Updated data and voter lists by March 27, 2020 (Diskominfo Jatim, 2019).

As for the maintenance of the 2020 Election, it covers (1) Terms of support for a single candidate on August 1, 2019, (2) Registration of the candidate pairs on 28 April 2020, (3) Tata Usaha Negara (state business administration) Election Dispute on June 13 2020, (4) Campaign Period on June 16, 2020, (5) Campaign Fund Report and Audit on June 15, 2020, (6) Procurement and Distribution of Voting Equipment on June 12, 2020, (7) Collection and counting on September 14, 2020, (8) recapitulation of the results of the vote count as of September 23, 2020, (9) Assignment of selected pairs without application of Election Result Dispute (PHP), (10) Voter results verification dispute (PHP), (11) determination of the couple of candidates selected after the decision of the Constitutional Court, (12) Following the confirmation of the appointment of the selected candidate couple and (13) additional evaluation and reporting (Diskominfo Jatim, 2019).

\section{The Candidates and Their Promises}

The voting process of Mayor Election 2020 in Surabaya will be held in December 9, 2020. There will be 2 pairs of mayoral candidates contested in the political election. Both pairs of candidates are 01 Eri CahyadiArmuji carried by PDIP (Indonesia Democracy Party) and 02 Mahfud Arifin-Mujiaman carried by 8 parties (PKB, PPP, PAN, Golkar, Gerindra, PKS, Demokrat and Partai Nasdem) (Faizal \& Khairina, 2020). Each has political promises that will be made if elected. In terms of their political campaign in environment, Eri Cahyadi-Armudji and Machfud ArifinMujiaman conveyed environmental handling to reduce urban temperatures and overcome micro-plastic waste during the third public debate in the Surabaya Pilkada (Kurniawan, 2020b). 


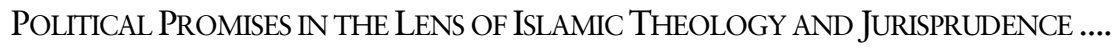

In terms of preparing good candidates, After the candidate's registration stage on September 4-6 2020, several stages have to be taken: (1) Health examination: September 4-11, 2020. (2) Delivery of health examination results: September 11-12, 2020. (3) Notification of verification results: September 13-14, 2020. (4) Submission of candidate improvement documents: September 14-16, 2020. (5) Verification of repair documents: September 16-22, 2020. (6) Determination of candidate pairs: September 23, 2020.

After selecting candidates, one of the important stages will be passed, which is the campaign period. Based on KPU Regulation Number 5 of 2020, the campaign period will run from September 26 to December 5, 2020 (Asmara, 2020).

As reported by liputan6.com, the third Surabaya regional head election (pilkada) public debate was held on Saturday, December 5, 2020. The third public debate was related to the Surabaya regional election with the theme of synergy of sustainable development with a national perspective. Each of the Surabaya pilkada candidate pairs, namely Eri Cahyadi-Armudji and Machfud Arifin-Mujiaman, delivered their vision and mission for a synergy of sustainable development with a national perspective in the debate (Kurniawan, 2020a).

Here are Eri Cahyadi-Armuji' political promises during their campaign: (1) Government-Entrepreneurs Collaboration. (2) Investment Facility. (3) Optimizing Micro Small and Medium Enterprise (MSME). (4) 30,000 MSMEs going up in class. (4) Increasing Co-Working Space. (5) Absorbing Workforce Prioritizing Local Citizens. (6) Making online transportation as Surabaya Tour Guides (Widarti, 2020)

Machfud Arifin-Mujiaman's political promises are as follow: (1) Enhancing Foreign Investment. (2) Optimizing the Role of Sister City. (3) Optimizing the corners of the city as a tourist destination. (4) Organizing Waste Management. (5) Creating a Teacher Welfare Policy. (6) Building a Transparent Bureaucracy. (7) Turning on the dead markets. (8) Advancing the creative economic sector. (9) Prospering fishermen (Widarti, 2020). 


\section{ASRORUN NIAM SHOLEH}

Based on the results of observations from several online media, it can be seen that each pair of candidates has been trying to convince Surabaya people to vote for them. The vision, mission and programs of the Surabaya Mayor candidate that will be carried out when elected are made as attractive as possible. Of course, these things cannot be separated from the success team's intervention. The promises and programs made range from environmental issues-city planning, economy-business-world of work, infrastructure and sustainable development. In this case, people will see, as well as candidate figures, the promises and programs that were conveyed and carried out during the campaign process. However, in reality, sometimes people feel disappointed because after a candidate has been elected they forget what was promised and ignore what was their commitment at the beginning of their campaign. Ideally, when they have been elected they should be committed to delivering on the promises and programs that have been voiced in their political campaigns. They must also involve the people to accelerate the fulfillment of these promises.

\section{Political Realism of Promises}

To theoretically highlight this case study, political promises are an arena and an opportunity for politicians to express their vision and mission, which are considered to favor the people's interests. The campaign period is momentum for politicians to convey their promises to the people. While the campaign itself has been regulated by the applicable law, even though the political campaign regulations are laden with black and negative campaigns (Pamungkas \& Arifin, 2019). In other words, the state has made it legal for politicians to deliver their political promises.

Meanwhile, socially and culturally, public awareness has accepted the reality of the campaign as a means of conveying political promises that tend to be dirty practices, one of which is the lack of transparency in campaign finance audits, questionable audit quality, issues of responsibility of parties in charge of auditing (Darmoko \& Ratnaningtyas, 2015). The dynamics that occur throughout the process of campaigning for candidates' ideas, promises, and commitments are accompanied by the 
socio-political reality of transactions (Solihah, 2017). The practice of political transactions started from the campaign period until later after the inauguration. It is known as the politics of reciprocation (Puri, 2019).

Transactional politics is a real consequence born during campaign moments precisely when the candidates face the public from various elements, both ordinary people and political brokers themselves. The contact between candidates and political brokers results in the decay of democracy often referred to as the political transaction. The meaning of political broker here is a certain social category that refers to individuals who play an important role in the success or failure of the battle process to the candidate's seat of power (Harnom et al., 2019). Brokers' role tends to undermine state rules that seek to create fair, fair, open, and transparent elections.

Through the General Election Commission (KPU) regulation, one aspect that is highlighted is the limit on the nominal contribution of campaign funds, both from the private sector, individuals and parties. In fact, candidates are required to have their bank account numbers. All of these rules are aimed at controlling and regulating limits on campaign funds, and to avoid transactional political practices. As an example, the KPU regulates that foreign parties, for example, may not contribute campaign funds (Widyaningrum, 2020).

The KPU regulations above do not touch deeper social dimensions, the operational areas of political brokers, who often justify all means and use various dirty strategies. This dark and behind-the-scenes social dimension cannot be denied because it was born from the political momentum for bargaining during the campaign period. For this reason, transparency and accountability of campaign funds are often neglected in democratic practice (Putra, 2018).

Bargaining between candidates and brokers rests on interests. On the one hand, the candidates' main goal is only one win, while on the other hand, the brokers' main goal is the profit from the capital spent to support the candidates' needs. In the past, when the broker's champion has won 


\section{ASRORUN NIAM SHOLEH}

the power struggle, the fulfillment of political promises can no longer be interpreted as a leader who fulfills his promises to the people but metamorphoses into other socio-political categories, such as corruption, collusion, and nepotism (Puyu, 2016).

Furthermore, the fulfillment of political promises by candidates who have been inaugurated and served as people's representatives could evolve into efforts to build a political dynasty. Gratitude for debt services and successful cooperation so far will naturally be maintained to continue from generation to generation. However, the brokers who funded the start's campaign process will be called ordinary people on the front stage as a friend on backstage.

These friendship politics creates a "patron-client" relational structure in politics. Patron-client politics becomes inevitable because patrons and clients are bound by agreements built for the same interests and on the momentum of spreading political promises. Political contracts are nothing but part of the pre-conditions for agreements between candidates and their supporters (Agustino, 2014).

Islamic jurisprudence cannot be dragged to legitimize the fulfillment of political promises, given that the characteristics of political promises (Akad siyasah) are the opposite of those of non-political promises. Forcing Islamic jurisprudence to justify the legality of fulfilling political promises is tantamount to legitimizing its derivative consequences, such as transactional politics, pre-client politics, political dynasties, and peak time KKN (Prianto, 2016).

The main obstacle to the objection of Islamic jurisprudence to validating political promises and fulfilling political promises is contextual, namely the preconditions that surround the formation of political agreements between candidates and their supporters. The precondition is a social reality where the supporters are not homogeneous as clean supporters. The existence of supporters who violate state legislation, such as bookies, capitalist investors, and other stowaways, color the creation of unhealthy social roles and categories for the sake of democracy (Fauzi, 2017). 
The supporters' heterogeneous reality is a social fact that has its consequences for efforts to legitimize Islamic jurisprudence on the status of political promises and the fulfillment of these promises. Because, in the principle of Islamic law (Ușūl al-Fiqh), staying away from a damage (mafsadat) takes precedence over pursuing benefit (maslahat) (Suhardi, 2019).

\section{Islamic Theology on The Political Promises}

In Islam, a promise is a debt. Everyone promising must keep it to do something immutable. It is obvious that Quran has blatantly instructed to do so with regard to keeping promises "And keep your promise with God when you promise and do not break those promises after confirming them ..." (QS. al-Nahl [16]: 91). In another verse, it is stated: "And keep the promise, verily the promise will be held accountable. " (QS. al-Isrā' [17]: $34)$.

In the prophetic tradition, those who frequently break promises are considered to be a hypocrite. Hypocrisy is very dangerous in terms of breaking social systems among people. the Great Prophet Muhammad (pbuh) said: "Hypocritical signs of someone are threefold; when they speak they lie, when they promise they break, and when they are trusted they were treason." (al-Naisyabūry, n.d.).

Breaking promises is included in the category of a sinfulness, and the level of the wickedness of the leader will affect the level of people's obedience to him. The tradition of the Prophet:

"There are four things to which if a person is accustomed, he is regarded as a true hypocrite, and whoever has in themselves one of these four things, he/she has the nature of hypocrisy until he leaves it. Namely, if he was given the mandate he was treasonous if he spoke a lie if he promised to deny and if he fought to cheat, " (al-Bukhārī, 2008).

Promises in social experience cannot be separated from their political dimensions. Political promises are nothing but just to get sympathetic vote and to gain power. Meanwhile, Islam teaches that in addition to mandate and not chasing positions, one of the important prerequisites for 


\section{ASRORUN NIAM SHOLEH}

candidates for public office is the fulfillment of the element of competence or abliyyah. The Prophet Muhammad (pbuh) reminded about competence in terms of leadership as a warning to Abi Dhar when he volunteered to become an official as tradition as follows:

"From Abu Dhar RA, he said: I ask, O Messenger of Allah, don't you please employ me? Then the Prophet tapped me on the shoulder and said: $\mathrm{O}$ Abu Dhar, you are weak. Being employed is a mandate. It will be a burden and regret on the Day of Resurrection, except for those who take it for their rights and fulfill it as it should, "(al-Naisyabüry, n.d.).

In those tradition, the Holy Prophet reminded Abi Dhar of Abi Dhar's condition, who was considered unworthy in carrying out the mandate due to his physical weakness and then reminded him that this position was a mandate that would bring regret on the Day of Judgment unless it was held by an expert and appropriately fulfilled that mandate.

Competence (ahliyyah) in terms of public leadership includes professional competence, in the sense that it can carry out the mandate; Personal competence in the sense that he is personally known as a figure worthy of leadership, and social competence in the sense that is acceptable to society. Leadership competence is the key to achieving maximum organizational performance (Suwatno, 2019, p. 2). The Holy Prophet also warned against giving leadership mandates to people who do not have the competence: From Abu Hurairah RA, Rasulullah (pbuh) said: "If the trust is wasted then wait for destruction to come." He asked: "how to waste it?" The prophet answered: "If the government is given to other than the experts, then wait for the destruction" (al-Bukhārī, 2008).

Thus, asking for a position is disgraceful, let alone seizing it. Especially for people who do not have adequate capabilities and/or who are known to be more competent. The decision to choose public leadership must be based on mandate and competence (abliyyah). Anyone should not choose a leader based solely on a worldly lure. The Prophet in his hadith emphasized the prohibition of choosing a leader just because of the worldly profit orientation.

"There are three people who on the day of resurrection will not be spoken to by Allah, are not looked upon, are not purified and they will receive a painful 
punishment, namely; people who have excess water in the Sahara desert but do not want to give it to travelers; people who make agreements with other people to sell merchandise after Asar, they swore by Allah that he had taken (bought) the item at this price and the other person believed it, when in fact it was not; people who take allegiance to leaders for the benefit of the world. If the leader gives him worldly benefits, he keeps his promises, but if not, then he doesn't keep his promises.” (muttafaq 'alaih; al-Bukhārī, 2008; alNaisyabūry, n.d.)

The tradition of the Prophet emphasizes the prohibition of obedience to a leader who orders immorality:"It is obligatory to obey Muslim leaders in terms of their likes and dislikes, as long as they are not ordered to commit immorality. If ordered to commit immoral acts, then there is no need to listen and obey them." (al-Qazwīnī, 1998; al-Turmudhi, 1989).

Here, the campaign call to elect a particular candidate has its legitimate foundation. Not only that, the promises of politicians during the political campaign period must be measured from the standard of religious morality. For example, in terms of obeying a leader, obeying a leader is obligatory as long as the orders and prohibitions are not against the sharia, as explicitly explained in the Koran as God says: "O you who believe, obey Allah and Allab's Apostle, and leaders among you. If you disagree about something, then return it to Allah (Quran) and Rasul (Sunnab), if you really believe in Allah and the day after. That is more important (for you) and better as a result” (QS. al-Nisā' [4]:59).

From the Islamic perspective, the position is a mandate that Allah holds to account for. For this reason, it is not appropriate to beg for office or even fight over it to the point of justifying any means. In connection with this mandate, Allah said: "Indeed, we have conveyed a mandate to the heavens, the earth, and the mountains, so all of them are reluctant to take up that mandate and they are worried that they will betray it, and humans bear it. Indeed, humans are very wrongdoers and very stupid" (QS. al-Aḥzāb [33]:72).

Considering its position as a mandate, it is not good to be fought over. However, when you have obtained the mandate and expressed the ability to accept it, whether you want it or not, like it or not, you must convey 


\section{ASRORUN NIAM SHOLEH}

that mandate. Suppose the mandate is related to the administration of the field of law. In that case, it must be enforced with the principle of justice, likewise if the mandate is in the executive and legislative fields. The Verse of God in QS al-Nisa 'affirms: "Verily, Allah instructs you to convey the message to those who have the right to receive it, and (instructs you) when establishing laws among humans so that you determine it fairly. Verily, Allah will give the best teaching to you. Indeed, Allah is All-hearing, Allseeing” (QS. al-Nisa' [4]:58).

Then the Prophet Muhammad emphasized the prohibition of asking for any position of leadership, as in his saying:

"O Abdurrahman, don't beg for a position because if you are given a position because of the result of begging then you will be burdened, and if you are given a position not based on begging then you will be helped by it. If you swear to do something but then you see a policy that is better than your oath then pay the kaffarat oath then do something better " (muttafaq 'alaih; alBukhārī, 2008; al-Naisyabūry, n.d.).

\section{Jurisprudence and Maxim of the Political Promises}

The empirical political reality that leads to negative values is a social problem that can be understood from Islamic law philosophy or Ușūl alFiqh. Through this lens, various negative attributes in political reality get their portion so that Islamic law's logic can provide answers and solve complex problems.

One of the Islamic legal maxim principles asserts that:

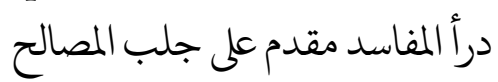

Dar'u al-mafāsid muqaddamun 'alā jalbi al-mașālị̣. It means: rejecting badness is prioritized over pursuing goodness (Suhardi, 2019). This basic principle can be used to see how the status of political promises and fulfillment of these promises will be when damages are inevitable.

In Ușūl al-Fiqh's view, the quality and quantity of badness can be measured by comparing it to the quality and quantity of the goodness that you want to pursue. In this case, the evils that must exist throughout the campaign period and the socialization of political promises must be endeavored to suppress to the minimum level. 
Therefore, the legal status of political promises and the various logical consequences therein must be interpreted or specified. First, a political promise whose harm is greater than any other political promises with less harm can be avoided. The next choice is directed at political promises with less harm. So that political promises with the minimum impact have a legitimate position or position in Islamic law.

Second, the various logical consequences of bad political promises, such as the practice of transactional politics, money politics, corruption, collusion and nepotism, the formation of political dynasties and client patrons, all of which can also be legitimized by Islamic jurisprudence. In other words, when these logical consequences cannot be avoided and must be dealt with, Islamic law only legitimizes practices whose adverse effects are at a minimum level.

This necessitates a view of Islamic legal maxim regarding several types of badness that can be tolerated, within certain limits and corridors, especially when the available options are only bad alternatives and no good. Islamic law serves as a shield against evil and supports all efforts that lead to resistance to evil.

At this level also, the reasoning of legal maxim can be built on the principles of other Ușūl al-Fiqh that emphasizes:

$$
\text { لا ضررولا ضرار }
$$

Là darara wa là dirāra (not detrimental to yourself and others) (Usamah, 2007). So that Islamic jurisprudence can legitimize sociopolitical actions that lead to efforts to save oneself and others. Political promises that aim to eradicate badness, eliminate suffering to the people, nation, and state, are in line with Islamic values.

Status as an Islamic or legitimate political promise in the view of Islamic jurisprudence is very important. This important value can be seen from how Islam supports these political promises. So, Muslims' social actions have a legal basis in giving full support to candidates who have certain political promises. 


\section{ASRORUN NIAM SHOLEH}

One of the principles of Islamic jurisprudence that can legitimize the social actions of Muslims in providing support to candidates, who carry an Islamic vision and mission and political promises, said:

$$
\text { مالا يتم الواجب الا به فهو واجب }
$$

Mà là yatimmu al-wāiib illā bibi fahuwa wājib (An obligation that is not perfect except through a certain thing, the thing becomes (also) obligatory) (Maula, 2014).

This principle uses a sociological-philosophical approach to show the legitimacy of Islamic jurisprudence against Muslims' social actions who must support candidates with political promises that are more relevant in implementing Islamic legal standards and realizing public goods. Ultimately, it is not only Islamic jurisprudence and Muslims that are obliged to support candidates with a vision and mission that are in line with Islamic values, but candidates who have officially been elected and appointed as rulers are also obliged to fulfill their political promises. Meanwhile, political promises that bring a little disadvantage must be made and disseminated to the public.

In conclusion, Islamic jurisprudence is directed to legitimize sociopolitical actions that brings a bit disadvantage (mudharat) as one of the principles says:

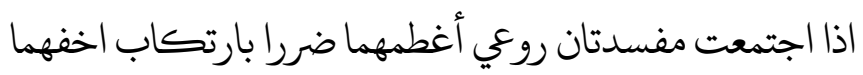

Idhā ijtama'at mafsadatāni ru'iya a'zhamuhumā dirāran bir tikābi akhaffibima (if two bad choices coincide, it has to be considered which the greatest is by doing the lightest (al-Wakili, 1997, p. 214).

In a political realism where disadvantages cannot be avoided, then the act of choosing and prioritizing the lightest disadvantage is in accordance with the logic of Islamic jurisprudence. Various dilemmas that arise as a result of political promises are punished in accordance with law from the main issue, namely the law of making political promises with constituents who propose points of agreement. 
POLITICAL PROMISES IN THE LENS OF ISLAMIC THEOLOGY AND JURISPRUDENCE ....

\section{The Various Dimensions of Political Promise}

From the explanation of the various dimensions of the candidate's political promises above, the Islamic jurisprudence or fiqh takes severallegal decisions. In simple terms, political promises made during the campaign period by leaders must be enforced. First, a promise to do something that is forbidden is prohibited ( haramm) to be fulfilled. Second, the promise to do something that is required is obliged to be fulfilled; and third, the promise to do something permissible must be fulfilled, but the scholars differ on whether it is obligatory $(w \overline{a j i} i b)$ or recommended (sunnah).

Most of Jurisprudence scholars stated that keeping promises is recommended (mustahab) and breaking them is not recommended (makruh). This, among others, was conveyed by Abul Ala 'alMubarakfuri quoting Imam al-Nawawi, who said:

"The scholars have agreed that whoever promises someone something that is not prohibited by religion must fulfill his promise. Whether the law fulfills that politics is obligatory or sunnah, the scholars have different opinions. Imam Syafi'i, Abu Hanifah, and most scholars say that fulfilling promises is recommended (sunnah). If not fulfilled, goodness will be lost and that person has done a very sad case even though he is not sinful" (al-'Uqba, 2017, p. 319).

In terms of the status of this leader's promise, Imam Ibn Hajar alAsqalani maintained:

"Indeed someone's promise is like a testimony against him, according to AlKirmani. Al-Mihlab states that fulfilling that promise is ordered and recommended for all Muslims but is not obligatory. Ibn Abdil Bar and Ibnul Arabi said that one that said so was Umar bin Abdul Aziz. Some scholars of the Maliki school hold: If the promise is related to a certain cause, it must be fulfilled, otherwise it is not obligatory, " (Al-Asqalani, n.d., p. 353).

In making promises, leaders' political policies must be based on the benefit of the public interest. Public policies may not be implemented except following the syara'. If it is contradictory then it cannot be implemented. This can be seen in al-Asbah wan Nazhair:

"If the leader's actions are just based on the benefit for the public interest then according to syara'the order should not be carried out unless in accordance 


\section{ASRORUN NIAM SHOLEH}

with syara'. If it is contradictory, it should not be implemented. In this case, Imam Abu Yusuf in his book al-Kharraj in the chapter of Ihya'u al-mawat stated: The leader (government) may not take anything out of anyone's hands except with permanent rights (rules) and in a good manner " (al-Suyūtị̂, 1998, p. 124).

Likewise, the view of Imam al-Qarafi al-Maliki in interpreting Qs. Al Isra ': 34 confirms that the leader has to considerably focus on carrying the mandate by taking public goods/ advantage (mașlahah) and getting rid of harmfulness:

"Know that whoever has power, from the caliphate to the smallest testament, must not do anything except those who bring benefit (maslahat) or prevent disadvantage (mafsadat), based on the verse of Allah" (QS. Al-Isrā [17]: 34).

Also the hadith that the Prophet said "Whoever is given a mandate (in the form of power) over my people, then do not mean it (benefit) them, and do not advise them, it is forbidden for him to enter heaven" (alQarafi, 2001, p. 1165).

It can also be seen from Ibn Nujaim's opinion that "Judges' actions that are allowed in the property of orphans, inheritance, and endowments, must be in relation to benefit (maslahat), if it is not so, it is not allowed" (Al-Suyūtịi, 1998, p. 139).

\section{Conclusion}

To sum up, the election preparation is "an expensive price" to pay. It is indeed set in a great and ordered mechanism. How every single thing is prepared maturely from searching, selecting and preparing candidates in a way very rigid and strict. Ideally, the candidates have to meet the requirements to fulfill the Surabaya citizens' aspirations and sustainable good governance.

In addition, Surabaya mayor election 2020 marks an important transition from the successful female mayor Tri Rismaharani. The political promises as well as programs of her successors would, to some extent, signify the sustainability of Surabaya good governance. However, in this case, the candidates' political promises should be seen as something inseparabale from the positive and negative sides. Various rules made in 
positive law, Islamic theology and jurisprudence are often violated. Consequently, the political reality requires politicians to be dragged into illegal and dirty practices, and all doors are closed to fully implement clean political practices.

In a completely stuck and deadlocked situation, the view of Islamic theology and jurisprudence provides concessions, with the principle that when humans are faced with alternatives that are both negative and do not contain maslahat, Muslims are encouraged to take the path that has the least adverse effects. So that Islamic jurisprudence in the form of Fiqh can provide strict boundaries, by legal status of political practice which must be contextual and conditional. Namely, while being able to avoid harm or damage, that is what is recommended. One of the characteristics of a socio-political behavior legitimized by Islamic jurisprudence is to benefit and take side with the wider public.[w]

\section{References}

Agustino, L. (2014). Patronase Politik Era Reformasi: Analisis Pilkada di Kabupaten Takalar dan Provinsi Jambi. Jurnal Administrasi Publik, 11(2), 69-82.

Ahmad, K. B. (2001). Relasi Islam dan Negara: Perspektif Modernis dan Fundamentalis. Magelang: Indonesia Tera.

al-Asqalani, I. H. (n.d.). Fathu al-Bari Syarh Shahih al-Bukhari.

al-Wakili, M. (1997). Fiqh al-Awlawiyāt: Dirasah fi al-Dawābiț. Virginia: al-Ma'had al-'Alamii li al-Fikr al-Islāmiy.

Anwar, Y., \& Adang, A. (2008). Pengantar Sosiologi Hukum. Jakarta: Grasindo.

Asmara, C. G. (2020, September 18). Catat! Masa Kampanye Pilkada 2020 Dimulai 26 September 2020. CNBC Indonesia.

Awalin, R., Arpan, A., \& Novera, A. (2018). Kekuatan Mengikat Janji yang Disampaikan dalam Kampanye Pemilihan Umum. Palembang: Universitas Sriwijaya.

al-Bukhārī, A. A. M. bin I. bin I. (2008). Șaḥị̣ al-Bukhārī. 'Ibād alRaḥmān. 


\section{ASRORUN NIAM SHOLEH}

Darmoko, H. W., \& Ratnaningtyas, D. (2015). Audit Dana Kampanye Pemilihan Umum Kepala Daerah Menurut Persepsi Partai Politik, Komisi Pemilihan Umum Daerah, dan Auditor Kantor Akuntan Publik. Jurnal Ekomaks, 4(1), 102-108.

Diskominfo Jatim. (2019, July 1). KPU: Tahapan Pilkada Surabaya 2020 Dimulai September 2019. Kominfo.Jatimprov.Go.Id.

Faizal, A., \& Khairina, K. (2020). Diusung 8 Partai di Pilkada Surabaya, Machfud Arifin Bantah Keroyok Calon PDI-P. Kompas.Com. https://regional.kompas.com/read/2020/09/20/21311361/diusung-8partai-di-pilkada-surabaya-machfud-arifin-bantah-keroyok-calonpdi

Fatimah, S. (2018). Kampanye sebagai Komunikasi Politik. Resolusi: Jurnal Sosial Politik, 1(1), 5-16. https://doi.org/10.2489/ resolusi.v1i1.154

Harnom, F., Syahrizal, S., \& Valentina, T. R. (2019). Pendidikan Politik bagi Pemilih Milenial dalam Memahami Bahaya Vote Broker oleh KPU. Nusantara: Jurnal Ilmu Pengetahuan Sosial, 6(1), 1-10. https://doi.org/10.31604/jips.v6i1.2019.1-10

Karim, A. G. (2020). Menegosiasi Ulang Indonesia. Yogyakarta: IRCiSoD.

Kurniawan, D. (2020a). Adu Visi Misi Eri Cahyadi-Machfud Arifin Terkait Sinergi Pembangunan Berkelanjutan - Surabaya. Liputan6.Com. https://surabaya.liputan6.com/read/4426381/aduvisi-misi-eri-cahyadi-machfud-arifin-terkait-sinergi-pembangunanberkelanjutan

Kurniawan, D. (2020b). Janji Eri Cahyadi dan Machfud Arifin Atasi Masalah Lingkungan di Surabaya. Liputan6.Com. https://surabaya. liputan6.com/read/4426409/janji-eri-cahyadi-dan-machfud-arifinatasi-masalah-lingkungan-di-surabaya

Magdalena, D. (2018). Penataan dan Pemberdayaan Pedagang Kaki Lima dari Janji Politik Pemilihan Kepala Daerah Serentak tahun 2017 dan Urgensinya dalam Pembentukan Peraturan Daerah. Jurnal Legislasi Indonesia, 14(2), 211-222.

Maula, B. S. (2014). Kajian Ahwal al-Syakhsiyyah dengan Pendekatan Maqasid al-Syari'ah. Al-Manabij: Jurnal Kajian Hukum Islam, 8(2), 233-246. https://doi.org/10.24090/mnh.v8i2.410

Monib, M., \& Bahrawi, I. (2011). Islam dan Hak Asasi Manusia dalam Pandangan Nurcholis Madjid. Jakarta: Gramedia. 
POLITICAL PROMISES IN THE LENS OF ISLAMIC THEOLOGY AND JURISPRUDENCE ....

Muayyad, U. (2015). Asas-asas Perjanjian dalam Hukum Perjanjian Islam. 'Anil Islam: Jurnal Kebudayaan dan Ilmu Keislaman, 8(1), 1-24.

al-Naisyabūry, M. bin al-Hajjāj A. al-Hasan al-Q. (n.d.). Șaḥị̣ Muslim. Beirut: Dār al-Fikr.

Octania, G. (2019). Pemaknaan Janji Politik Calon Presiden Prabowo Subinato-Sandiaga Uno di Kompas TV (Analisis Resepsi pada Komunitas Jurnalis Berhijab). JIKA: Jurnal Ilmu Komunikasi Efek, 3(1), 75-93. https://doi.org/10.32534/jike.v3i1.759

Pamungkas, A. D., \& Arifin, R. (2019). Demokrasi dan Kampanye Hitam dalam Penyelenggaraan Pemilihan Umum di Indonesia (Analisis atas Black Campaign dan Negative Campaign). Diktum: Jurnal Syariah dan Hukum, 17(1), 16-30. https://doi.org/10.35905/diktum.v17i1. 641

Prianto, B. (2016). Partai Politik, Fenomena Dinasti Politik dalam Pemilihan Kepala Daerah, dan Desentralisasi. Publisia: Jurnal Ilmu Administrasi Publik, 1(2), 105-117. https://doi.org/10.26905/pjiap. v1i2.436

Puri, W. H. (2019). Politik Balas Budi, Buah Simalakama dalam Demokrasi Agraria di Indonesia. Masalah-Masalah Hukum, 48(4), 355. https://doi.org/10.14710/mmh.48.4.2019.355-365

Putra, H. (2018). Mendorong Transparansi dan Akuntabilitas Dana Kampanye pada Penyelenggaraan Pilkada Serentak Tahun 2018. JPPUMA: Jurnal Ilmu Pemerintahan Dan Sosial Politik Universitas Medan Area, 6(2), 112-121. https://doi.org/10.31289/jppuma. v6i2.1622

Puyu, D. S. (2016). Paradigma Fiqh al-Hadits terhadap Perilaku Poliitk Kontemporer. Al-Qalam, 22(1), 117-130. https://doi.org/10.31969/ alq.v22i1.268

al-Qarafi, A. b-S. (2001). Kitāb al-Furuq: Anwār al-Buruq fi Anwā̄i alFurul. Cairo: Dār al-Salām.

al-Qazwīnī, al-Hāfiz A. A. M. ibn Y. ibn M. (1998). Sunan Ibn Majah. Dār al-Hadìth.

Rizkika, H. L., Ummah, H., Raider, A. W., \& Rahmawati, E. I. (2019). Banal Politik Transaksional Para Pemilih (Tinjauan Psikologis). Insight: Jurnal Pemikiran Dan Penelitian Psikologi, 15(2), 289-300. https://doi.org/10.32528/ins.v15i2.2094

Safrun, S. R., Abdullah, M. Z., \& Husain, M. N. (2020). Kajian Komunikasi Politik Anggota DPRD Muna Barat dalam Merealisasikan Janji Kampanye pada Pilcaleg 2014. Publica: Jurnal 


\section{ASRORUN NIAM SHOLEH}

Administrasi Pembangunan dan Kebijakan Publik, 11(1), 184-193. https://doi.org/10.33772/publica.v11i1.13533

Solihah, R. (2017). Politik Transaksional dalam Pilkada Serentak dan Implikasinya bagi Pemerintahan Daerah di Indonesia. The Politics: Jurnal Magister Ilmu Politik Universitas Hasanuddin, 2(1), 97-109.

Suhardi, A. R. (2019). Analisis Kaidah Dar'u al-Mafasid Muqaddamun 'ala Jalbi al-Mashalih dari Aspek Ontologis Epistemologis dan Aksiologis. UIN Sunan Gunung Djati Bandung.

Susan, N. (2009). Sosiologi Konflik: Teori-teori dan Analisis. Jakarta: Kencana Predana Media Group.

Suseno, H., \& Putra, N. K. (2014). Perspeksi Publik Perkotaan terhadap Janji Politik Caleg menurut Faktor Budaya, Sosial, Pribadi dan Psikologis. Jurnal Penelitian, 18(1), 67-77.

Susmayanti, R. (2019). Analisis Putusan tentang Gugatan Wanprestasi terhadap Pengingkaran Janji Kampanye oleh Presiden Terpilih. Jurnal Supremasi, 9(1), 39-50. https://doi.org/10.35457/supremasi. v9i1.577

Suwandi, M. (2019). Perempuan dan Politik Islam. Yogyakarta: Deepublish.

Suwatno, S. (2019). Pemimpin dan Kepemimpinan dalam Organisasi Publik dan Bisnis. Jakarta: Bumi Aksara.

Suwendra, I. W. (2018). Metodologi Penelitian Kualitatif dalam Ilmu Sosial, Pendidikan, Kebudayaan dan Keagamaan. Bandung: Nilacakra.

al-Suyūțī, J. A. (1998). al-Ashbāh wa'l-Nazāir. Dār al-Kutub al-'Ilmiyyah.

Tim Dakwah Pesantren. (2015). Tanya Jawab Agama Islam. Yogyakarta: PISS-KTB.

al-Turmudhi. (1989). al-Jāmi’ al-Sabịh Sunan al-Turmudhi. Beirut: Dār Ihyā'.

al-'Uqba, A. S. (2017). al-Sabīl fì Ușūl al-Fiqh. Beirut: Dār al-Kutub al'Ilmiyyah.

Usamah, A. (2007). Qa'dah lā Darar wa lā Dirār fì Nithaq al-Mu'āmalat al-Māliyah wal A'māl al-Ṭibbiyah al-Mu'asirah fī al-Figh al-Islāmiy wa Qanūn al-Qadhī. Iskandariah: Dār al-Jamī’ah al-Jadīdah.

Widarti, P. (2020). Pilkada Surabaya, Kilas Balik Janji Kampanye Kedua Paslon Wali Kota. Surabaya.Bisnis.Com. https://surabaya.bisnis. 
POLITICAL PROMISES IN THE LENS OF ISLAMIC THEOLOGY AND JURISPRUDENCE ....

com/read/20201209/531/1328595/pilkada-surabaya-kilas-balikjanji-kampanye-kedua-paslon-wali-kota

Widyaningrum, H. (2020). Pelarangan Pihak Asing sebagai Pemberi Sumbangan Dana Kampanye Pemilu. Krtha Bhayangkara, 14(1), 70-85. https://doi.org/10.31599/krtha.v14i1.38

Yasid, A. (2019). Logika Ushul Fiqh. Yogyakarta: IRCiSoD.

Zed, M. (2004). Metode Penelitian Kepustakaan. Jakarta: Yayasan Obor Indonesia. 
The page was intentionally left blank. 